\title{
REGIONAL PATTERNS OF BELONGING AMONG YOUNG LATVIAN RETURNEES
}

\author{
Elina Apsite-Berina ${ }^{1}$, Dr. geogr., Researcher; Zaiga Krisjane ${ }^{2}$, Dr.geogr., Professor; \\ Guido Sechi ${ }^{3}$, PhD., Researcher; Maris Berzins ${ }^{4}$, Dr. geogr., Assistant Professor \\ $1,2,3,4$ University of Latvia, Faculty of Geography and Earth Sciences
}

\begin{abstract}
This paper investigates return migration to Latvia and explores the profiles of young return migrants to core and peripheral parts of the country. Traditionally, return migrants are viewed as potential human capital that can be reinvested in the country of origin. At individual level, the attraction to the region or city of origin has an important emotional aspect and a sense of belonging to a certain place. Despite the level of satisfaction, self-valued gains from international experience and difficulties the individual needs to overcome upon return, the feeling of belonging and longing for home often overcomes the economic aspects of return. This is particularly important when describing a group of young adults and geographically looking at different marginal and core places.

As an analytic framework, return migration concepts explain several aspects that wreathe individual return migration decision. Returnees' profiles of core and peripheral parts of the country describe individual's longing for home with a background of migration experience.

Authors draw on empirical materials from Horizon2020 YMOBILITY project and reflect on data from survey and interviews with Latvians who have returned from the main destination countries and currently reside in core or peripheral parts of the country. Research indicates that returnees to peripheral parts are mostly married men with children, holding secondary vocational education and who are skilled manual workers. Returnees to the core part are mostly single women with up to tertiary education level and employment in clerical or administrative fields. Pieriga exceptionally attracts those who are homesick, while Zemgale and Kurzeme attract those who wish to live and work, because they feel attached to these places and desire to reside there.
\end{abstract}

Key words: return migration, Latvia, core, periphery, belonging, migrant profiles.

JEL code: R110, J110

\section{Introduction}

Since the accession to European Union (EU), Latvia has witnessed increased mobility both in terms of internal and international migration. It is especially characteristic to non-metropolitan and predominantly rural regions, which have experienced an outstanding population decline mainly due to out-migration of young adults. This problem is largely discussed among academics and highly important to the society. Many studies on migration in Europe have emphasized the regional patterns not only for out-migration, but also for return and circular movements (Cassarino, 2004; Engbergsen et al., 2013; Farell et al., 2014; King, 2017; King and Williams, 2017). Recent study on intra-EU youth mobility patterns reveals that both emigration and return migration decisions consider socioeconomic, cultural aspects as well as place specific aspects within which individuals' migration decisions are made (Sandu et al., 2017). Even more, return migration is an important issue for the regions and settlements of the sending country (Farell et al., 2012; Nadler et al., 2014; Coniglio and Brzozowski, 2018). Furthermore, previous studies have provided empirical evidence for the relationships between place attachments, belonging and spatial mobility (Gustafson, 2006; Du, 2017). Despite the growing interest, migrants' bonding with their place of origin appears less researched, especially in the case of young returnees. There is a substantial amount of literature on the subject of emigration from Latvia, but understanding about the impact of migration on place attachment and belonging is limited.

Aim of the research is to explore the composition of young adults and motivation behind the return decision in the light of place attachment and belonging. In general, one particular question is addressed - how important is the place of origin in the era of globalisation and increased mobility. Empirically, tasks of the study are to extend the existing knowledge of place attachment 
and belonging in migration studies by analysing young adults returning to their home regions and to highlight individual experiences. Based on the previous research, several socioeconomic, cultural, family and psychological aspects induce return migration (King, 1978; Williams and Balaz, 2005; Zaiceva and Zimmermann, 2012; Lados and Hegedus, 2016). Regarding the regional patterns, authors distinguish between core regions (the city of Riga and the Pieriga region) and peripheral regions (Zemgale, Kurzeme, Vidzeme and Latgale).

Authors draw on empirical materials from Horizon2020 YMOBILITY project and reflect on data from the survey and interviews with return migrants (up to 35 years old). Pan European survey took place in nine European countries with total number of 30000 respondents in 2015 and 2016. Total number of survey respondents and interviewees was, respectively, 311 and 70 young returnees. Available data allowed using a mixed methodological approach, identifying main profiles and individual experiences of return migration of young returnees to the regions of Latvia.

\section{Profile of young returnees: core and periphery}

The typical profile of a young Latvian returnee to core and peripheral regions is as follows (Table 1). People up to age of 35 were surveyed in this study, and the average age of returnees is above 27 years. More women have returned to Riga and Pieriga, while the share of men is higher in peripheral regions. Civil status figures display sharp differences. More people who are single without children have returned to core parts. Young returnees to peripheral regions are more likely to be married or in a partnership and with children. This mostly relates to family reunification processes. Overall, the most common level of education in Latvia is secondary or vocational education. This is also the case with the respondents of peripheral regions. Core regions of Latvia attract more young returnees with secondary education and compared to periphery there is a much higher share of people with tertiary education (respectively, $25.5 \%$ and $14.5 \%$ ). In this context, Riga can possibly attract more young returnees who wish to study or continue studies. There are also noticeable differences when analysing current occupational status of young returnees. Overall, the most common occupational status after return is employment as skilled manual; the least common is student. In the case of Riga and its surroundings, the most common status is clerical and administrative work, and the least common is low-skilled physical work. In the case of periphery, returnees are mostly skilled and other manual workers, while students make up the smallest group. Possibility of return migration correlates with time spent abroad - majority of surveyed young returnees have lived and worked or studied for a period of approximately 1 to 2 years. Possibility to return permanently decreases with the increase of time spent abroad.

Besides the profile of a typical returnee, it was essential to analyse the geographical aspect of the return motives of those who returned (Table 2). 17 return motives of respondents were ranked according to the mean values for peripheral regions and the core part of Latvia. The motives were also arranged according to the highest mean values. Overall, the main return motives relate to homesickness, taking care of family in Latvia (case of Kurzeme), reuniting with a partner or starting a family (case of Zemgale) and wishing to raise children in Latvia (Kurzeme). These results show the importance of longing for home and the attachment to the place of origin. Moreover, Kurzeme and Zemgale regions are the most attractive ones for returnees whose return is family related. 
Respondent characteristics, ( \%)

Descriptive characteristics of Latvian returnees

\begin{tabular}{|c|c|c|c|}
\hline & $\begin{array}{l}\text { All returnees } \\
\text { to Latvia }\end{array}$ & Core & Periphery \\
\hline \multicolumn{4}{|l|}{ Gender } \\
\hline Women & $51.1 \%$ & $57.70 \%$ & $49.30 \%$ \\
\hline Men & $49.9 \%$ & $42.30 \%$ & $50.70 \%$ \\
\hline Average age (years) & 27.55 & 27.91 & 27.21 \\
\hline \multicolumn{4}{|l|}{ Civil status } \\
\hline Single without children & $36.3 \%$ & $43.80 \%$ & $30.90 \%$ \\
\hline Single parent & $2.9 \%$ & $3.60 \%$ & $2.00 \%$ \\
\hline Married / partner without children & $13.5 \%$ & $13.10 \%$ & $13.20 \%$ \\
\hline Married / partner with child/children & $39.5 \%$ & $29.20 \%$ & $48.00 \%$ \\
\hline Separated/divorced/widowed without children & $2.6 \%$ & $3.60 \%$ & $2.00 \%$ \\
\hline Separated/divorced/widowed with child/children & $5.1 \%$ & $6.60 \%$ & $3.90 \%$ \\
\hline \multicolumn{4}{|c|}{ Educational level } \\
\hline Primary education or less & $6.8 \%$ & $5.1 \%$ & $8.6 \%$ \\
\hline Secondary education & $33.8 \%$ & $29.2 \%$ & $37.5 \%$ \\
\hline Post-secondary non-tertiary education & $32.5 \%$ & $24.1 \%$ & $37.5 \%$ \\
\hline First stage of tertiary education & $18.6 \%$ & $25.5 \%$ & $14.5 \%$ \\
\hline Second stage of tertiary education & $8.4 \%$ & $16.1 \%$ & $2.0 \%$ \\
\hline \multicolumn{4}{|c|}{ Current occupational status } \\
\hline Manager or professional & $12.8 \%$ & $17.80 \%$ & $8.70 \%$ \\
\hline Clerical and other administrative & $18.1 \%$ & $28.10 \%$ & $10.10 \%$ \\
\hline Skilled manual & $21.7 \%$ & $17.80 \%$ & $21.50 \%$ \\
\hline Other manual & $13.5 \%$ & $5.90 \%$ & $20.80 \%$ \\
\hline Student & $6.3 \%$ & $7.40 \%$ & $6.00 \%$ \\
\hline House-person, caring, and other not in employment & $7.6 \%$ & $5.90 \%$ & $10.10 \%$ \\
\hline Seeking a job & $9.5 \%$ & $7.40 \%$ & $12.10 \%$ \\
\hline Other & $10.5 \%$ & $9.60 \%$ & $10.70 \%$ \\
\hline \multicolumn{4}{|c|}{ Duration of stay abroad } \\
\hline 1 year or less & $35.1 \%$ & $33.1 \%$ & $37.0 \%$ \\
\hline 1-2 years & $25.4 \%$ & $25.4 \%$ & $25.3 \%$ \\
\hline 2-3 years & $16.3 \%$ & $15.4 \%$ & $17.1 \%$ \\
\hline 3-5 years & $14.1 \%$ & $16.2 \%$ & $12.3 \%$ \\
\hline $5-7$ years & $5.1 \%$ & $3.8 \%$ & $6.2 \%$ \\
\hline 7-10 years aboard & $2.2 \%$ & $3.8 \%$ & $0.7 \%$ \\
\hline more than 10 years abroad & $1.8 \%$ & $2.3 \%$ & $1.4 \%$ \\
\hline Total and responses with geographic identification & 311 & 137 & 152 \\
\hline
\end{tabular}


Return motivations by region, (rank)

Table 2

\begin{tabular}{|c|c|c|c|c|c|c|c|}
\hline & \multirow{2}{*}{ Region/Return motive } & \multicolumn{4}{|c|}{ PERIPHERY } & \multicolumn{2}{|c|}{ CORE } \\
\hline & & Zemgale & Kurzeme & Latgale & Vidzeme & Riga & Pieriga \\
\hline 1 & Homesickness & 2 & 3 & 6 & 4 & 5 & 1 \\
\hline 2 & To take care of the family & 6 & 1 & 5 & 3 & 4 & 2 \\
\hline 3 & $\begin{array}{l}\text { To get married / be with a } \\
\text { partner and form a family }\end{array}$ & 1 & 2 & 6 & 5 & 4 & 3 \\
\hline 4 & $\begin{array}{l}\text { For children to grow up in home } \\
\text { country }\end{array}$ & 2 & 1 & 5 & 3 & 6 & 4 \\
\hline 5 & Migration aims achieved & 1 & 4 & 6 & 5 & 2 & 3 \\
\hline 6 & $\begin{array}{l}\text { Return home to complete my } \\
\text { training/studies }\end{array}$ & 2 & 5 & 3 & 6 & 1 & 4 \\
\hline 7 & Personal problems & 1 & 3 & 6 & 5 & 2 & 4 \\
\hline 8 & General welfare/ life quality & 2 & 3 & 6 & 5 & 1 & 4 \\
\hline 9 & Cheaper cost of living & 1 & 2 & 6 & 3 & 4 & 5 \\
\hline 10 & $\begin{array}{l}\text { Better job prospects/income in } \\
\text { home country }\end{array}$ & 1 & 2 & 6 & 5 & 3 & 4 \\
\hline 11 & To have my own house & 4 & 1 & 2 & 6 & 3 & 5 \\
\hline 12 & Health problems & 1 & 2 & 6 & 4 & 3 & 5 \\
\hline 13 & $\begin{array}{l}\text { Difficult socio-cultural } \\
\text { environment }\end{array}$ & 1 & 4 & 6 & 2 & 3 & 5 \\
\hline 14 & $\begin{array}{l}\text { Expired work permit/or failed to } \\
\text { get extension to permit }\end{array}$ & 3 & 5 & 1 & 6 & 2 & 4 \\
\hline 15 & $\begin{array}{l}\text { Temporary stay/ end of studies } \\
\text { or contract }\end{array}$ & 2 & 4 & 3 & 5 & 1 & 6 \\
\hline 16 & $\begin{array}{l}\text { To create a new business at } \\
\text { home }\end{array}$ & 1 & 2 & 4 & 6 & 3 & 5 \\
\hline 17 & Company transfer & 1 & 4 & 5 & 3 & 2 & 6 \\
\hline
\end{tabular}

The overall highest mean value, and the rank, relates to homesickness for return migrants originating from Pieriga. This is explained by the large number of crisis migrants (McCollum et al., 2016), who emigrated from Pieriga during the period of economic crisis as a way of economic rescue to secure the housing purchased in this area.

The capital city of Riga has characteristic features relating to students and planned returns. According to the analysis, most common reasons for returning to Riga were the desire to complete or continue studies or the temporary nature of their initial stay abroad. Return to Vidzeme region, is unique in comparison to other regions, because none of the motivational factors have the highest rank; thus it represents mixed return motivations. Latgale region displays the lowest positions in rank for the majority of the mentioned motives. There is, however, one distinction - persons who returned to Latgale mostly did it because their work permits expired or they failed to get an extension. Besides taking care of family and wanting their children to grow up in Latvia, Kurzeme region has the highest potential for returnees to purchase or inherit real estate and to settle down. Interestingly, Zemgale region has numerous leading positions in the return motivation ranking, but relating to both positive and negative aspects. Besides the previously mentioned positive family motives, personal problems and health issues are present. It seems that returnees to Zemgale had strategically planned their emigration - compared to other regions returnees have achieved their migration aims. Gain and loss evaluation reveals that it is cheaper to live in Zemgale than in the 
country of destination; also, the region offers similar or even better job prospects and income and is more welcoming when it comes to creating a business.

From the combination of return motivations and returnees' profiles, it is evident that peripheral (particularly Zemgale and Kurzeme regions) attract skilled workers with secondary or vocational education, who are in a partnership, with children and wish to live and work, because they feel attached to these places and desire to reside there.

\section{Longing for home: individual returns}

The main countries of destination for returnees to Latvia are the UK, Ireland, Germany and Sweden. 28 interviewed individuals returned from the UK, 24 from Germany, 10 from Ireland and 8 returned from Sweden. From 30 people who reside in the core part of the country, 20 people lived there before emigration. Peripheral distribution shows that before emigration, 28 people lived in a small/medium size town, while 12 lived in small villages or rural areas. After the return, this proportion has slightly changed as 12 people currently live in medium size towns and 8 others remain living in small villages, most often in the family property they originated from.

15 people have spent less than 2 years abroad. 23 people have spent two to three years abroad, 12 others have spent three to five years there. The remaining 10 have lived abroad for a period of up to 14 years.

In terms of occupation, students and high skilled returnees mostly returned to Riga, while ones with lower skilled occupations returned to peripheral parts.

As identified in previous sections, survey result analysis of qualitative data reveals predominance of attachment to the place of origin, longing for home and importance of one's regional identity, which in many cases is more important than national or European identity.

Results suggest that international migration as a form of experience urges young Latvians to question and contribute more to personal understanding of cultural and social identity matters. Being away from their common environment allows testing one's ability to integrate in a strange environment and at the same time to value their own culture, tolerance towards other nationalities etc. Simultaneously, personal gains and opportunities are highly valued by students.

Following quotes indicate the importance of return migrant issues related to belonging illuminated throughout in-depth interviews where positive assertiveness was evident among returnees from both core and peripheral parts. Seemingly, those returning to Riga relate to Latvia as a whole "In Latvia I feel at home. While I was abroad, I felt like going home all the time (Men, 36, UK, Riga, married, children)" and "I am definitely a Latvian, I belong to Latvia. But Latvia as a cultural entity and cultural identity cannot be separated (Man, 37, Riga, low skilled, no partner, no children)".

International migration experience is seen as an enriching experience that allows to respect ones' own cultural values and to gain a good understanding of various other cultures. Understandably, integration to host societies is not acceptable for all migrants, thus, in the case of Latvian returnees' international experience is valued positively, but longing for home has triggered the return: "I am certainly about Latvia, about Latvian traditions, culture, language and everything that is related to Latvia. I have changed my views and attitude towards other cultures, other nations, because I have had chance to get to know them. I view people differently, because I have gained experience during my work abroad. (Woman, 33 years, UK, periphery, married, no children, high skilled)" 
Internationally, it is often a task and a struggle to represent and to inform others about a small country from Eastern Europe. There are different levels of knowledge when it comes to specific identity features for different countries. In this quote, the returnee is proud of holding Latvian identity and tries to educate others on national identity features: "there are times when Latvian pride is coming out and people are asking - if I am Latvian. However, in other places, when I have been abroad and people see no difference between-Latvia, Lithuania, Russia, I always have my Latvian identity. Abroad, yes, my Latvian identity is always important. (Woman, 35, Sweden, high, married, children, Riga)".

Experience abroad forces students to step out of their comfort zone and after this experience, they appreciate opportunities provided in Latvia: "It [identity] strengthened in Germany as there were such different cultures represented. In that environment, you are very conscious of your own origin, identity and feel how much value is there when people around you talk in your native language. It is a great freedom and an opportunity to study at a place that has good qualities, in the home country, in your native language, with people who think alike. Many green forests around. (Man, Germany, Riga, student, no partner, no children)".

Comparison between core and peripheral parts of the country shows slight differences in how they perceive the feeling of home. Returnees to peripheral parts, compared to returnees to Riga, exemplify a more nuanced view on belonging to rural places: "I feel at home in rural areas. I work with rural girls at school; I see that their parents are interested in those [identity/belonging] things. Sure, it is countryside, this region; the county would be too strongly to say, maybe, but villages - Palsmane, Blome for sure. I do feel at home in Smiltene. (Man, Sweden, 35, periphery, married, children, high skilled; abroad low skilled)." "It will be in Latvia! I might even say that the whole Latvia. Whatever city or countryside. At the moment, I feel at home in Latvia (Woman, 27, UK, low skilled, periphery, married, children)."

Interesting aspect found in the interview material relates to young returnees with mixed background (Latvian - Russian, Latvian - other nationality, Russian, originating from eastern part of Latvia). For them, the question of national identity seems irrelevant and not important: "For some time, I could not make a choice, because my father is from Russia, but mother is Latgalian. I grew up in Daugavpils, where many people speak Russian. As I grew up in Daugavpils, there was no question of nationality, Latvians, Russians, Poles, Latgalians - we were communicating without mentioning ones' nationality. I speak Latvian well, but due to my accent, you can tell that I am not $100 \%$ Latvian. For me, national identity issue is not a problem. A man, who lives abroad also becomes patriotic and homesickness appears. The identity of belonging to Latvia is important to me, but for people it is more important to live in harmony (Man, UK, 37, low, periphery, no children, no partner)."

This group of people represents regional differences where the category of national identity plays no role, but the feeling of home and belonging to Latvia is characterised as very relevant. "In Latvia. I was born here. I usually said that I am Russian because the of people majority do not know where Latvia is. Those who know something, repeatedly ask about Lithuania. Few know about Latvia; it is easier to say I am Russian (Man, 29, periphery, high skilled, partner, no children)." 


\section{Conclusions, proposals, recommendations}

1) Returnees to peripheral regions are more likely to be married men with children, holding secondary vocational education and who are skilled manual workers. Returnees to the capital city and the core area are more likely to be single women with up to tertiary education level and employment in clerical or administrative fields.

2) From the combination of return motivations and returnees' profiles, it is evident that peripheral regions -in particular, Zemgale and Kurzeme - attract skilled workers with secondary or vocational education who are in partnership with children and wish to live and work, because they feel attached to their place of origin and desire to reside there.

3) While being abroad, separated from common environment and living among people of other nationalities, young migrants strengthen their views. Being away from the homeland is perceived as way of trying to find oneself and to understand their own feelings about the country of birth. Identity is closely linked to personal independence. Understanding of ones' individual identity traditionally relates to transition to adulthood, which is strongly influenced by independent life abroad. At the same time, international experience and the opportunity to study and work abroad is highly valued.

4) Overall, the most prevalent motives for return migration is homesickness, taking care of family in Latvia (characteristic to Kurzeme region), willingness to be reunited with a partner or having a family (Zemgale), and wishing to raise children in Latvia (Kurzeme). Sense of belonging to the country and regions in particular is a very important factor when it comes to return migration processes.

5) The sense of belonging to a rural place seems to have a strong influence on return migration decisions; returnees to the capital city reveal a more strategically planned return related to work and studies.

\section{Acknowledgments}

The research leading to these results received funding from the Horizon 2020 YMOBILITY project (Youth Mobility: Maximising Opportunities for Individuals, Labour Markets and Regions in Europe), grant agreement no. 649491. and the National Research Program [grant number 5.2.4].

\section{Bibliography}

1. Cassarino, J. P. (2004). Theorising Return Migration: The Conceptual Approach to Return Migrants Revisited. International Journal on Multicultural Societies. 6(2): 253-279.

2. Coniglio, N. D,. Brzozowski, J. (2018). Migration and Development at Home: Bitter or Sweet Return? Evidence from Poland, European Urban and Regional Studies, 25(1), 85-105.

3. Du, H. (2017). Place Attachment and Belonging Among Educated Young Migrants and Returnees: the Case of Chaohu, China. Popul. Space Place 2017; 23; e1967.

4. Engbersen, G., A. Leerkes, I. Grabowska-Lusinska, E. Snel, and J. Burgers. (2013). On the Differential Attachments of Migrants from Central and Eastern Europe: A Typology of Labour Migration. Journal of Ethnic and Migration Studies 39 (6): 959-981. doi: 10.1080/1369183X.2013.765663

5. Farrell, M, Kayrite, E., Nienaber, B., McDonagh, J. Mahon M. (2014) Rural Return Migration: Comparative Analysis between Ireland and Lithuania. Central and Eastern European Migration Review 3(2): 127- 149

6. Farrell, M., Mahon, M, McDonagh, J. (2012). The Rural as a Return Migration Destination. European Countryside. 4 (1)·31-44. DOI: 10.2478/v10091-012-0012-9

7. Gustafson, P. (2006). Place Attachment and Mobility. In Multiple Dwelling and Tourism: Negotiating Place, Home and Identity. McIntyre, Williams DR, McHugh k (eds) CAB International:Wallingford; $17-31$.

8. King, R (1978) Return Migration: a Neglected Aspect of Population Geography. Area 10(3): 175-182.

9. King, R, Williams, A.M. (2017). Editorial introduction: New European Youth Mobilities. Popul Space Place. e2121. https://doi.org/10.1002/psp. 2121

10. King, R. (2017). Theorising New European Youth Mobilities. Popul Space Place. 2017; e2117. https://doi.org/10.1002/psp. 2117 
11. Lados, G., Hegedus, G. (2016) Returning home: An evaluation of Hungarian return migration. Hungarian Geographical Bulletin 65(4), 321-330.

12. McCollum, D., Apsite-Berina, E., Berzins, M \& Krisjane, Z. (2016). Overcoming the crisis: the changing profile and trajectories of Latvian migrants, Journal of Ethnic and Migration Studies, DOI : $10.1080 / 1369183 X .2016 .1232161$

13. Nadler, R., Kovacs, Z. Glorius, B., Lang, T. (Eds) (2016) Return Migration and Regional Development in Europe. Mobility Against the Stream. Palgrave Macmillan UK.

14. Sandu, D, Toth, G, Tudor, E. (2018). The Nexus of Motivation-Experience in the Migration Process of Young Romanians. Popul Space Place. 2018;24:e2114. https://doi.org/10.1002/psp. 2114

15. Williams, A.M, Balaz, V (2005) What Human Capital, Which Migrants? Returned Skill Migrants to Slovakia From the UK. International Migration Review 39(2):439-468.

16. Zaiceva, A. and Zimmermann, K. F., (2012). Returning Home at Times of Trouble? Return Migration of EU Enlargement Migrants During the Crisis. IZA Discussion Papers7111, Institute for the Study of Labor (IZA). 